\title{
RETURNS OF SICKNESS FROM SHIPS OF THE ROYAL NAVY (1945-46): A CONTRIBUTION TO MEDICAL CLIMATOLOGY*
}

\author{
BY \\ J. A. FRASER ROBERTS
}

(From the Department of Medical Statistics, London School of Hygiene and Tropical Medicine)

A new short-term summary sickness return was instituted in the Royal Navy in July, 1945. The Admiralty Fleet Order calling for the new return is appended and explains its purpose and mechanism (Appendix). It was limited to ships carrying a medical officer and did not apply to shore establishments or hospital ships. The primary purpose was the collection of statistics that would have a bearing on questions of habitability. For the first time the attempt was made to utilize minor sickness, and so the return called for counts of those on the Attending List as well as those on the Sick List and those discharged to hospital. It was anticipated that Attending List figures might perhaps prove a better index of living conditions than more serious illness necessitating absence from duty.

Ships offer special advantages for this type of study. They bear a self-contained community with a relatively stable population. Changes in personnel are relatively small and gradual over considerable periods. The numbers at risk can be stated with accuracy. Such factors as changes in climatic conditions and differences in ship design can be readily studied in regard to their influence on fitness.

\section{BASIS OF RETURNS}

The returns are based on a weekly census count and the weekly sickness rates are calculated by taking the average of the figures for sickness at the beginning and end of the week and dividing by the similarly averaged complement. Actually, monthly (4- and 5-week) rates have been principally employed. It will thus be appreciated that in regard to Sick and Attending Lists the rates so calculated are the average percentages on those Lists during the week or month. Case incidence and duration of sickness

- Report prepared for the Habitability Sub-Committee of the Royal Naval Personnel Research Committee of the Medical Research Council. are not ascertained; one sickness of two weeks' duration makes the same contribution as two sicknesses each of a week's duration. Patients discharged to hospital had to be treated differently, as this sometimes involved being written off the ship's books. The return called for numbers discharged to hospital during the week. As a rough approximation-where large numbers are being compared-the average duration of stay in hospital has been taken at three and a half weeks. Hence the figures shown in the tables are simply average weekly discharges to hospital multiplied by $3 \cdot 5$.

The period covered by this review is the first year of the operation of the new return: August, 1945, to July, 1946, inclusive. (It should perhaps be mentioned that the Return could not have been instituted earlier as there were security objections to detailing the movements of ships in documents such as these.) For the main analysis it was decided to calculate rates for complete 4- (or 5-) weekly periods only. The total numbers available, amounting in the aggregate to $1,600,000$ man-weeks, were smaller than had been hoped. The reasons are as follows:

1. The Return was different from any previous form and thus was quite unfamiliar to medical officers and sick-berth ratings. Hence many returns were incomplete and faulty and had to be discarded.

2. Some time naturally elapsed before the Return could be instituted in ships in Far Eastern waters.

3. Returns covering periods when ships were in dockyard hands and giving extensive leave on return from foreign stations had to be discarded. This loss was considerably increased owing to the return home of ships following the end of the war. 
4. Another complication aggravated by the end of the war was the use of ships for carrying large numbers of military personnel not members of the ship's company. This difficulty had not been foreseen when the Admiralty Fleet Order was issued, and it seemed likely that not infrequently sickness amongst such personnel was returned, but they were not correspondingly shown in the strength of the ship's company. Accordingly returns covering ships used in this way were also discarded.

The remarks which medical officers were invited to append proved very useful in deciding which returns should be discarded. It should be mentioned in this connexion that no return was excluded because the rates seemed suspiciously high or suspiciously low. It is clear that views differed, particularly as to what should constitute an Attending List case. The effect of this should be random, however, when the figures of sufficient ships are added together. It may be hoped that with further experience greater uniformity will be secured and the trends which the figures already show will become yet more clear. At present it would te quite unsafe to compare a single ship with another single ship. Accordingly, in this review comparisons are limited either to fairly large aggregates, or to changes within a single ship, in which the standard may be expected to remain fairly uniform over periods of a few weeks or months.

\section{TYPES OF WATERS}

The aggregate returns covering complete 4- or 5-week periods from ships of all types in waters of all types are broken down in different ways in the tables. Table I shows a break-down by type of waters. These were divided into:

1. Northern temperate, mostly home and North Atlantic.

\section{TABLE I}

Comparison of Average Percentage Sickness Rates in Different Waters

(For definitions of disease groups see Admiralty Fleet Order given as Appendix)

\begin{tabular}{|c|c|c|c|c|c|c|c|}
\hline & & $\begin{array}{l}\text { Northern } \\
\text { temperate }\end{array}$ & $\begin{array}{l}\text { Southern } \\
\text { temperate }\end{array}$ & $\begin{array}{l}\text { Mediterran- } \\
\text { ean }\end{array}$ & Tropical & Mixed* & Total \\
\hline \multicolumn{2}{|l|}{ Man-weeks } & 303,700 & 195,080 & 94,370 & 499,780 & 499,030 & $1,591,960$ \\
\hline $\begin{array}{l}\text { Attending List } \dagger \\
\text { Upper respiratory .. } \\
\text { Dysenteries and diarrhoeas } \\
\text { Skin }\end{array}$ & \begin{tabular}{ll|} 
& \\
$\ldots$ & \\
arrhoeas \\
$\ldots$ & $\cdots$ \\
$\ldots$ & $\cdots$ \\
$\ldots$ & $\cdots$ \\
$\ldots$ & $\cdots$
\end{tabular} & $\begin{array}{l}0.66 \\
0.05 \\
1.59 \\
0.30 \\
1.71 \\
0.65\end{array}$ & $\begin{array}{l}0.63 \\
0 \cdot 11 \\
2 \cdot 30 \\
0.76 \\
1 \cdot 31 \\
0.88\end{array}$ & $\begin{array}{l}0.83 \\
0.40 \\
2 \cdot 74 \\
0.43 \\
2.63 \\
1.58\end{array}$ & $\begin{array}{l}0 \cdot 84 \\
0 \cdot 23 \\
5 \cdot 10 \\
1 \cdot 30 \\
2 \cdot 20 \\
1 \cdot 26\end{array}$ & $\begin{array}{l}0.79 \\
0.19 \\
2.95 \\
0.78 \\
1.95 \\
1.05\end{array}$ & $\begin{array}{l}0.76 \\
0.18 \\
3 \cdot 28 \\
0.83 \\
1.94 \\
1.05\end{array}$ \\
\hline Total & . $\quad \ldots$ & $4 \cdot 95$ & $5 \cdot 99$ & $8 \cdot 60$ & $10 \cdot 92$ & $7 \cdot 73$ & $8 \cdot 04$ \\
\hline \multicolumn{2}{|c|}{ Total (less venereal diseases) } & $4 \cdot 65$ & $5 \cdot 23$ & $8 \cdot 17$ & $9 \cdot 62$ & $6 \cdot 95$ & $7 \cdot 21$ \\
\hline $\begin{array}{l}\text { Sick List } \ddagger \\
\text { Upper respiratory } \\
\text { Dysenteries and di } \\
\text { Skin . . . . } \\
\text { Venereal diseases } \\
\text { Other diseases } \\
\text { Injuries .. }\end{array}$ & \begin{tabular}{cc|} 
& \\
arrhoeas & \\
$\ldots$ & $\cdots$ \\
$\ldots$ & $\cdots$ \\
$\cdots$ & $\cdots$ \\
$\ldots$ & $\cdots$
\end{tabular} & $\begin{array}{l}0.21 \\
0.01 \\
0.07 \\
0.01 \\
0.15 \\
0.08\end{array}$ & $\begin{array}{l}0.25 \\
0.04 \\
0 \cdot 16 \\
0.09 \\
0 \cdot 18 \\
0 \cdot 12\end{array}$ & $\begin{array}{l}0 \cdot 25 \\
0 \cdot 07 \\
0 \cdot 16 \\
0 \cdot 03 \\
0 \cdot 32 \\
0 \cdot 18\end{array}$ & $\begin{array}{l}0 \cdot 26 \\
0 \cdot 11 \\
0 \cdot 27 \\
0 \cdot 10 \\
0 \cdot 34 \\
0 \cdot 15\end{array}$ & $\begin{array}{l}0.28 \\
0.04 \\
0 \cdot 15 \\
0 \cdot 04 \\
0 \cdot 31 \\
0 \cdot 14\end{array}$ & $\begin{array}{l}0.25 \\
0.06 \\
0.17 \\
0.06 \\
0.27 \\
0.13\end{array}$ \\
\hline Total & .. & $0 \cdot 52$ & $0 \cdot 82$ & $1 \cdot 00$ & $1 \cdot 22$ & $0 \cdot 95$ & 0.94 \\
\hline \multicolumn{2}{|c|}{ Total (less venereal diseases) } & $0 \cdot 51$ & $0 \cdot 73$ & 0.97 & $1 \cdot 12$ & 0.91 & $0 \cdot 88$ \\
\hline \multirow[t]{2}{*}{$\begin{array}{l}\text { In hospital } \| \\
\text { Total }\end{array}$} & \multirow{2}{*}{$\begin{array}{ll}\cdots & \cdots \\
l & \text { diseases) }\end{array}$} & $0 \cdot 81$ & $1 \cdot 12$ & $1 \cdot 36$ & $0 \cdot 84$ & $0 \cdot 49$ & $0 \cdot 78$ \\
\hline & & $0 \cdot 77$ & 0.87 & $1 \cdot 26$ & $0 \cdot 70$ & 0.46 & $0 \cdot 68$ \\
\hline
\end{tabular}

* Months spent in more than one type of water.

$\dagger$ Including light duty list. For definitions etc., see Appendix.

Excused duty.

II Approximate: average weekly discharges x 3.5. 
2. Southern temperate, mostly temperate Australian waters.

3. Mediterranean waters.

4. Tropical waters.

5. Mixed. Returns were included in the above four categories only if the whole of the 4- or 5-week period had been spent in waters of the same type. It is an indication of the great mobility of the ships that about a third of the experience is provided by returns from ships which had spent monthly periods in more than one type of water as defined above. Such experience is all added together under this fifth mixed heading.

The individual broad disease classification proved quite unsuitable for cases discharged to hospital. Accordingly these are shown as totals only. As already explained, the returns gave cases discharged to hospital during the week. The figures have been converted into values roughly comparable to the
Sick and Attending List rates by assuming an average stay in hospital of three and a half weeks. These figures are not of much interest in the present review, but are included for completeness.

\section{TYPES OF SHIP}

Table II shows the same material broken down by type of - ship. It soon became evident that differences between ships of different types were small compared with differences between ships of any type in different types of water. Accordingly broad classifications have been used for Table II.

The various types of ships shown in this table did not have the same amount of experience in waters of the various types shown in Table I. For example, depot, maintenance, and repair ships spent proportionately more time in tropical waters than the rest. Hence the figures are presented again for Attending and Sick Lists in Table III, but this time weighted so that the proportion of experience of

\section{TABLE II}

Comparison of Average Percentage Sickness Rates in Different Types of Ships: All Waters

\begin{tabular}{|c|c|c|c|c|c|c|}
\hline & Battleships* & $\begin{array}{l}\text { Aircraft } \\
\text { carriers }\end{array}$ & Cruisers & $\begin{array}{l}\text { Destroyers, } \\
\text { corvettes, } \\
\text { etc. }\end{array}$ & $\begin{array}{l}\text { Depot, repair, } \\
\text { maintenance, } \\
\text { etc. }\end{array}$ & Total \\
\hline Man-weeks & 204,680 & 567,930 & 466,570 & 105,450 & 247,330 & $1,591,960$ \\
\hline 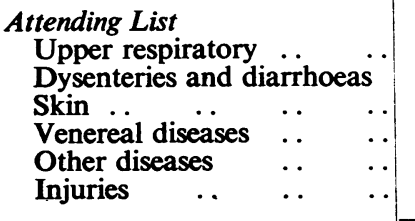 & $\begin{array}{l}0 \cdot 63 \\
0 \cdot 13 \\
2 \cdot 12 \\
1.45 \\
1.60 \\
0 \cdot 66\end{array}$ & $\begin{array}{l}0 \cdot 71 \\
0 \cdot 17 \\
2 \cdot 87 \\
0 \cdot 64 \\
1 \cdot 91 \\
0 \cdot 93\end{array}$ & $\begin{array}{l}0 \cdot 79 \\
0 \cdot 18 \\
3 \cdot 61 \\
0 \cdot 59 \\
1 \cdot 97 \\
1 \cdot 04\end{array}$ & $\begin{array}{l}0 \cdot 82 \\
0 \cdot 10 \\
3 \cdot 44 \\
0 \cdot 73 \\
1 \cdot 63 \\
1 \cdot 31\end{array}$ & $\begin{array}{l}0 \cdot 91 \\
0 \cdot 26 \\
4 \cdot 50 \\
1 \cdot 23 \\
2 \cdot 39 \\
1 \cdot 58\end{array}$ & $\begin{array}{l}0 \cdot 76 \\
0 \cdot 18 \\
3 \cdot 28 \\
0 \cdot 83 \\
1 \cdot 94 \\
1 \cdot 05\end{array}$ \\
\hline Total & $6 \cdot 58$ & $7 \cdot 22$ & $8 \cdot 17$ & $8 \cdot 03$ & $10 \cdot 87$ & $8 \cdot 04$ \\
\hline Total (less venereal diseases) & $5 \cdot 13$ & $6 \cdot 58$ & $7 \cdot 58$ & $7 \cdot 30$ & $9 \cdot 64$ & $7 \cdot 21$ \\
\hline 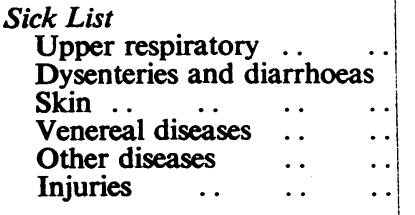 & $\begin{array}{l}0 \cdot 23 \\
0 \cdot 03 \\
0 \cdot 20 \\
0 \cdot 12 \\
0 \cdot 21 \\
0 \cdot 12\end{array}$ & $\begin{array}{l}0 \cdot 27 \\
0 \cdot 05 \\
0 \cdot 15 \\
0 \cdot 04 \\
0 \cdot 27 \\
0 \cdot 12\end{array}$ & $\begin{array}{l}0 \cdot 25 \\
0 \cdot 05 \\
0 \cdot 15 \\
0 \cdot 03 \\
0 \cdot 26 \\
0 \cdot 11\end{array}$ & $\begin{array}{l}0 \cdot 28 \\
0 \cdot 05 \\
0 \cdot 18 \\
0 \cdot 10 \\
0 \cdot 24 \\
0 \cdot 13\end{array}$ & $\begin{array}{l}0 \cdot 22 \\
0 \cdot 13 \\
0 \cdot 23 \\
0 \cdot 07 \\
0 \cdot 36 \\
0 \cdot 18\end{array}$ & $\begin{array}{l}0 \cdot 25 \\
0.06 \\
0 \cdot 17 \\
0 \cdot 06 \\
0 \cdot 27 \\
0 \cdot 13\end{array}$ \\
\hline Total & 0.91 & 0.91 & 0.85 & $0 \cdot 98$ & $1 \cdot 18$ & 0.94 \\
\hline Total (less venereal diseases) & $0 \cdot 79$ & $0 \cdot 87$ & $0 \cdot 82$ & $0 \cdot 88$ & $1 \cdot 11$ & $0 \cdot 88$ \\
\hline $\begin{array}{l}\text { In hospital } \uparrow \\
\text { Total }\end{array}$ & 0.67 & $0 \cdot 60$ & 0.94 & 0.94 & 0.91 & $0 \cdot 78$ \\
\hline Total (less venereal diseases) & $0 \cdot 56$ & $0 \cdot 53$ & $0 \cdot 81$ & $0 \cdot 81$ & $0 \cdot 77$ & 0.68 \\
\hline
\end{tabular}

- Attending List rates for battleships too low. See text.

$\dagger$ Average weekly discharges x 3.5. 
the different types of waters is the same for ships of all types. The Mediterranean did not provide sufficient returns for some kinds of ships, so the Mediterranean figures were added to the mixed category.

\section{SeÁsonal Variations}

The figures for temperate waters have been broken down according to season in Table IV. Upper respiratory disease only is separated from the rest, and even in regard to this it is only northern temperate waters that show any appreciable seasonal variation. There is no particular trend to discern in regard to other diseases, so these are shown in total only.

\section{Relative Rates}

In Tables V and VI the data of interest of Tables I and III are represented with one category reduced to 100 for each disease group, which may make it easier to follow the trends. It must be emphasized, however, that too much importance must not be attached to the magnitudes of relative rates which are based on low absolute rates, for example the dysenteries and diarrhoeas; the proportionate contribution to total sickness is small and the relative rates, being based on small numbers, are subject to larger chance errors. It should also be mentioned that the relative rates were calculated directly from the percentage rates of the earlier tables, which are given to two places of decimals only; hence the rounding-off of the relative rates based on small absolute rates.

The figures of Table IV, broken down according to season, showed little variation except in upper respiratory diseases in northern temperate waters. Accordingly Table VII gives monthly relative rates for these waters for Attending List only, the rates being shown in terms of 100 as the average for the whole year. As in all tables in this review, totals are weighted, that is to say, a total rate is the total number of sicknesses divided by the total number of man-weeks, and is not a simple average of rates calculated on varying numbers.

\section{Study of TABLes I-VII}

A study of the preceding Tables I-VII points to fairly definite conclusions. It is evident that the really important contributions to variations in percentage sickness is the type of water. Tables I and $V$ show that the total rates are rather more than doubled in tropical as against northern temperate waters. The effect is greatest, as might be anticipated, in the dysenteries and diarrhoeas, but, of course, the absolute numbers are small. Diseases of the skin, which bulk so largely in the Attending List, are multiplied more than three times. Skin diseases are not quite so important in the Sick List, but the rise in tropical waters is proportionately even greater. Injuries share in the

\section{TABLE III}

Comparison of Average Percentage Sickness Rates in Different Types of Ships: weighted to give same Proportion OF EXPERIENCE IN EACH TYPe OF WATER

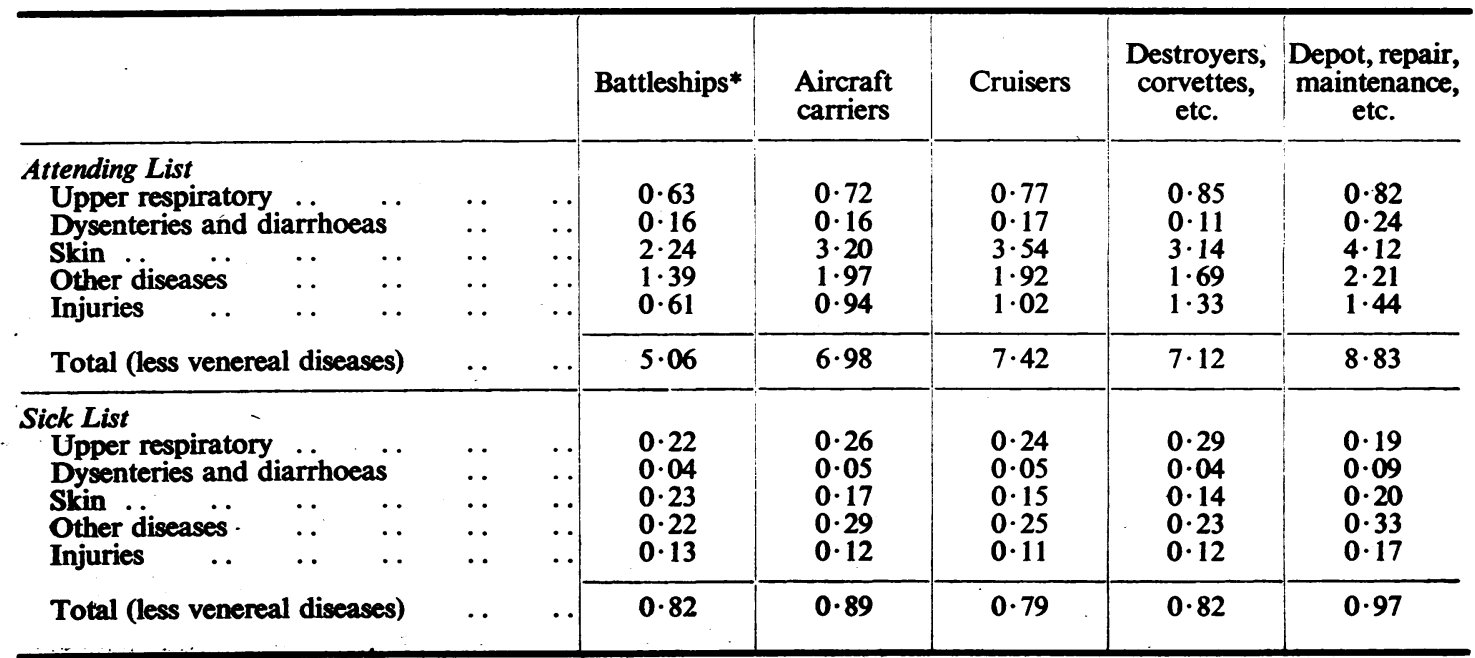

- Attending List rates in battleships too low. See text. 
TABLE IV

Comparison by Season of Average Percentage Sickness Rates in Temperate Waters

\begin{tabular}{|c|c|c|c|c|c|c|}
\hline & \multicolumn{3}{|c|}{ Northern } & \multicolumn{3}{|c|}{ Southern } \\
\hline & $\begin{array}{c}\text { Hot } \\
\text { (June-Sept.) }\end{array}$ & $\begin{array}{l}\text { Medium } \\
\text { (April-May, } \\
\text { Oct.-Nov.) }\end{array}$ & $\begin{array}{c}\text { Cold } \\
\text { (Dec.-Mar.) }\end{array}$ & $\begin{array}{c}\text { Hot } \\
\text { (Dec.-Mar.) }\end{array}$ & $\begin{array}{l}\text { Medium } \\
\text { (April-May, } \\
\text { Oct.-Nov.) }\end{array}$ & $\begin{array}{c}\text { Cold } \\
\text { (June-Sept.) }\end{array}$ \\
\hline $\begin{array}{l}\text { Attending List } \\
\text { Upper respiratory } \\
\text { All others } \\
\text { diseases) }\end{array}$ & $\begin{array}{l}0.56 \\
4.04\end{array}$ & $\begin{array}{l}0.61 \\
3.83\end{array}$ & $\begin{array}{l}0.94 \\
4 \cdot 19\end{array}$ & $\begin{array}{l}0.60 \\
4.91\end{array}$ & $\begin{array}{l}0.67 \\
3.76\end{array}$ & $\begin{array}{l}0.69 \\
4.62\end{array}$ \\
\hline $\begin{array}{l}\text { Sick List } \\
\text { Upper respiratory } \\
\text { Ull }\end{array}$ & $\begin{array}{l}0.20 \\
0.29\end{array}$ & 0.28 & $\begin{array}{l}0.30 \\
0.35\end{array}$ & 0.52 & $0 \cdot 16$ & $\begin{array}{l}0.32 \\
0.43\end{array}$ \\
\hline
\end{tabular}

TABLE V

Comparison of Relative Sickness Rates in Different Waters: Northern Temperate Waters $=100$

\begin{tabular}{|c|c|c|c|c|c|c|}
\hline & & $\begin{array}{l}\text { Northern } \\
\text { temperate }\end{array}$ & $\begin{array}{l}\text { Southern } \\
\text { temperate }\end{array}$ & $\begin{array}{l}\text { Mediterran- } \\
\text { ean }\end{array}$ & Tropical & Mixed \\
\hline $\begin{array}{l}\text { Attending List } \\
\text { Upper respiratory } \\
\text { Dysenteries and diarrhoeas } \\
\text { Dkin . } \\
\begin{array}{llll}\text { Skin } & . \\
\text { Other diseases } & \ldots & \ldots \\
\text { Injuries } \quad . & \ldots & \ldots\end{array}\end{array}$ & $\begin{array}{l}\because \\
\because \\
\because \\
\cdots\end{array}$ & $\begin{array}{l}100 \\
100 \\
100 \\
100 \\
100\end{array}$ & $\begin{array}{r}95 \\
220 \\
145 \\
77 \\
135\end{array}$ & $\begin{array}{l}126 \\
800 \\
172 \\
154 \\
243\end{array}$ & $\begin{array}{l}127 \\
460 \\
321 \\
129 \\
194\end{array}$ & $\begin{array}{l}120 \\
380 \\
186 \\
114 \\
162\end{array}$ \\
\hline Total (less venereal diseases) & .. & 100 & 112 & 176 & 207 & 149 \\
\hline 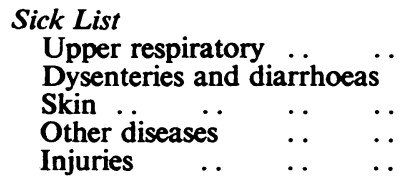 & $\begin{array}{l}\cdots \\
\because \\
\because \\
.\end{array}$ & $\begin{array}{l}100 \\
100 \\
100 \\
100 \\
100\end{array}$ & $\begin{array}{l}119 \\
400 \\
229 \\
120 \\
150\end{array}$ & $\begin{array}{l}119 \\
700 \\
229 \\
213 \\
225\end{array}$ & $\begin{array}{r}124 \\
1,100 \\
386 \\
227 \\
188\end{array}$ & $\begin{array}{l}133 \\
400 \\
214 \\
207 \\
175\end{array}$ \\
\hline Total (less venereal diseases) & .. & 100 & 143 & 190 & 220 & 178 \\
\hline
\end{tabular}

general rise. In this connexion it must be emphasized once again that the figures are not case incidences. The rises in tropical waters are doubtless due both to increased case incidence and to the greater duration of sicknesses.

The expectation that the Attending List might prove a more sensitive index of habitability than the Sick List is not completely realized. The trends in the Sick List figures are somewhat clearer and the rise somewhat greater. But it must not be forgotten that Attending List cases are ten times more numerous, hence far more Sick List returns have to be collected in order to establish a given proportionate increase than is necessary with Attending List figures. In fact Attending List figures are so large that monthly or even weekly fluctuations in a single large ship may prove meaningful. It is far more difficult to decide what constitutes an Attending List case, when the man is merely on light duty or full duty, than it is to define a Sick List case with the more definite criterion that the man is excused from all duty. It is possible that if Attending List cases could be defined more rigidly and a greater uniformity of procedure develops in regard to the Return, the Attending List would be the more valuable index, not only because of the greater numbers, but absolutely.

Differences between ships of the various types, shown in Table II, are small compared with variations between waters. Some even of the difference 
Comparison of Relative Sickness Rates in Different Types of Ships: Aircraft Carriers $=100$. Weightrd to give SAMe Proportion of EXPERIENCe IN EACH TYPe OF WATER

\begin{tabular}{|c|c|c|c|c|c|c|c|}
\hline & & & $\begin{array}{l}\text { Aircraft } \\
\text { carriers }\end{array}$ & Battleships* & Cruisers & $\begin{array}{l}\text { Destroyers, } \\
\text { corvettes, } \\
\text { etc. }\end{array}$ & $\begin{array}{l}\text { Depot, repair, } \\
\text { maintenance, } \\
\text { etc. }\end{array}$ \\
\hline 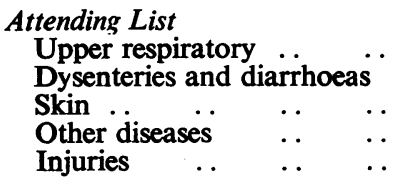 & $\begin{array}{l}\ldots \\
\cdots \\
\cdots \\
\cdots\end{array}$ & $\begin{array}{l}\because \\
. \\
. \\
. \\
.\end{array}$ & $\begin{array}{l}100 \\
100 \\
100 \\
100 \\
100\end{array}$ & $\begin{array}{r}88 \\
100 \\
70 \\
71 \\
65\end{array}$ & $\begin{array}{r}107 \\
106 \\
111 \\
97 \\
109\end{array}$ & $\begin{array}{r}118 \\
69 \\
98 \\
86 \\
141\end{array}$ & $\begin{array}{l}114 \\
150 \\
129 \\
112 \\
153\end{array}$ \\
\hline Total (less venereal diseases) & .. & .. & 100 & 72 & 106 & 102 & 127 \\
\hline 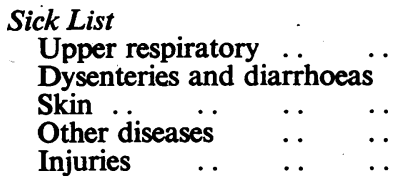 & $\begin{array}{l}\cdots \\
\cdots \\
\cdots \\
\cdots\end{array}$ & $\begin{array}{l}. \\
. \\
. \\
.\end{array}$ & $\begin{array}{l}100 \\
100 \\
100 \\
100 \\
100\end{array}$ & $\begin{array}{r}85 \\
80 \\
135 \\
76 \\
108\end{array}$ & $\begin{array}{r}92 \\
100 \\
88 \\
86 \\
92\end{array}$ & $\begin{array}{r}112 \\
80 \\
82 \\
79 \\
100\end{array}$ & $\begin{array}{r}73 \\
180 \\
118 \\
114 \\
142\end{array}$ \\
\hline Total (less venereal diseases) & . & & 100 & 92 & 89 & 92 & 109 \\
\hline
\end{tabular}

* Attending List rates for battleships too low. See text.

that does exist disappears when the experience of each type of ship is equalized for different waters, as in Tables III and VI. It must be mentioned here that the Attending List figures for battleships are unduly favourable. In one battleship, which contributes nearly a third of the experience, it is evident that the medical officers defined an Attending List case a good deal more rigidly than in the average ship, the figures being consistently very low. This did not apply to the Sick List in this ship, which was, if anything, above the average. For this reason aircraft carriers have been used to provide the standard rates of 100 in Table VI. Bearing this in mind, it is seen that there is no appreciable variation in Attending List figures except in the depot, repair, and maintenance ships, which, even after equalizing for type of water, show a total rate appreciably above the rest. This was expected. Such ships spend long periods in harbour, exposed to shore diseases, and habitability in some is known to be somewhat unsatisfactory. There is also the possibility that a greater average age of the ship's company may have produced some effect. Nevertheless, the general conclusion is clear: type of ship is of very small effect on minor sickness as compared to type of water. The Sick List figures of Table VI are, as regards the totals at least, remarkably constant.

Tables IV and VII show how small is the effect of season as compared with variation in type of water. There is the definite and expected winter rise in upper respiratory disease in northern temperate waters and that is all.

The figures for cases discharged to hospital do not reveal any apparently meaningful trends, except that the lower rates in battleships and aircraft carriers are an indication of their greater facilities for treating relatively serious illnesses aboard. It is the less serious illness represented by Attending and Sick Lists which provides the better index of habitability.

\section{TABLE VII}

Comparison of Average Percentage Sickness Rates BY MONTHS IN NORTHERN TEMPERATE WATERS (ATTENDING LIST ONLY): AVERAGE FOR TWELVE $\cdot$ MONTHS $=100$

\begin{tabular}{|c|c|c|c|c|}
\hline \multicolumn{3}{|c|}{ Month } & $\begin{array}{l}\text { Upper } \\
\text { respiratory }\end{array}$ & $\begin{array}{c}\text { All others (less } \\
\text { venereal diseases) }\end{array}$ \\
\hline $\begin{array}{l}\text { Aug., } \\
\text { Sept. } \\
\text { Oct. } \\
\text { Nov. } \\
\text { Dec. } \\
\text { Jan., } \\
\text { Feb. } \\
\text { March } \\
\text { April } \\
\text { May } \\
\text { June } \\
\text { July }\end{array}$ & $\begin{array}{c}1945 \\
\text { " } \\
" \\
19446 \\
" \\
" \\
" \\
",\end{array}$ & $\begin{array}{l}\ldots \\
\ldots \\
\ldots \\
\ldots \\
\ldots \\
\ldots \\
\ldots \\
\ldots \\
\ldots \\
\ldots\end{array}$ & $\begin{array}{r}71 \\
97 \\
91 \\
117 \\
94 \\
212 \\
203 \\
133 \\
73 \\
68 \\
94 \\
65\end{array}$ & $\begin{array}{r}100 \\
107 \\
95 \\
88 \\
82 \\
111 \\
134 \\
118 \\
113 \\
98 \\
96 \\
95\end{array}$ \\
\hline Total & $\ldots$ & $\ldots$ & 100 & 1.00 \\
\hline
\end{tabular}


MOVEMENT From Temperate to Tropical Waters

It was hoped when the Return was instituted that changes in the sickness rates in individual ships as they moved from one type of environment to another would be particularly instructive. Whatever the differences of procedure might be from ship to ship, standards in a single ship should remain fairly constant over relatively short periods. During the year under review, however, the number of ships whose returns could be used in this way was disappointingly small. The extreme mobility of ships was one factor which made comparison difficult. Changes from one type of water to another, for example, were so frequent that it proved difficult to obtain a run of figures in waters of one type even over a few weeks. Then all the factors which necessitated the discarding of returns, as already discussed, broke the sequence, often repeatedly, in many ships. Faulty returns, use of ships as transports, ships being in dockyard hands and giving leave to large numbers of the company, prevented in ship' after ship the analysis of returns covering a sufficient period. Actually in only two ships, an aircraft carrier and a submarine depot ship, was it possible to make an analysis of movement from temperate to tropical waters covering a fairly extensive period. Both ships had a similar experience. In both the returns covered six weeks spent in temperate Australian waters, followed by passage into the tropics, where the ships stayed for four months. The trends in both ships were very similar, and the complements (an average aggregate for both together of 1,900) not very dissimilar. Accordingly in Table VIII they are added together, thus serving to smooth out minor fluctuations.

It is at once apparent how useful is the Attending List. The numbers are large, the weekly figures of those on the List varying from a minimum of 112 to a maximum of 250. The trend is clear. By the second week in tropical waters the total Attending

\section{TABLE VIII}

Weekly. Percentage Sickness Rates in Two Shits, an Aircraft Carrier and a Submarine Depot Shit, in Temperate Australian Waters, followed by a Period in Tropical Waters (Venereal Diseases and Hospital Discharges omitted)

\begin{tabular}{|c|c|c|c|c|c|c|c|c|c|c|c|}
\hline & & & & & \multicolumn{6}{|c|}{ Attending List } & \multirow{2}{*}{$\begin{array}{c}\text { Sick List } \\
\text { Total }\end{array}$} \\
\hline & & & & & $\begin{array}{l}\text { Upper } \\
\text { respiratory }\end{array}$ & $\begin{array}{l}\text { Dysenteries } \\
\text { and } \\
\text { diarrhoeas }\end{array}$ & Skin & $\begin{array}{l}\text { Other } \\
\text { diseases }\end{array}$ & Injuries & Total & \\
\hline $\begin{array}{l}\text { Tempera } \\
\text { 1st we } \\
\text { 2nd } \\
\text { 3rd } \\
\text { 4th } \\
\text { 5th } \\
\text { 6th }\end{array}$ & $\begin{array}{l}\text { ate } A t \\
\text { eek } \\
\text { " } \\
\text { " } \\
\text { "” }\end{array}$ & $\begin{array}{l}\text { alia } \\
. \\
\because \\
. \\
. \\
\therefore \\
.\end{array}$ & $\begin{array}{c}\text { aters } \\
\ldots \\
\ldots \\
\ldots \\
\ldots \\
\ldots \\
\ldots\end{array}$ & $\begin{array}{l}\cdots \\
\cdots \\
\cdots \\
\cdots \\
\cdots\end{array}$ & $\begin{array}{l}0.92 \\
0.57 \\
0.50 \\
0.67 \\
0.74 \\
0.84\end{array}$ & $\begin{array}{c}0.05 \\
0.02 \\
- \\
0.02 \\
- \\
-\end{array}$ & $\begin{array}{l}3 \cdot 39 \\
3 \cdot 47 \\
3 \cdot 49 \\
4 \cdot 09 \\
2 \cdot 76 \\
2 \cdot 87\end{array}$ & $\begin{array}{l}1.25 \\
1.35 \\
1.35 \\
1.47 \\
0.79 \\
1.05\end{array}$ & $\begin{array}{l}1.52 \\
1.90 \\
1.72 \\
1 \cdot 37 \\
0.98 \\
1 \cdot 27\end{array}$ & $\begin{array}{l}7 \cdot 13 \\
7 \cdot 31 \\
7 \cdot 06 \\
7 \cdot 62 \\
5 \cdot 27 \\
6 \cdot 03\end{array}$ & $\begin{array}{l}0.72 \\
0.65 \\
0.54 \\
0.67 \\
0.92 \\
0.89\end{array}$ \\
\hline \multicolumn{5}{|c|}{ Week of entry into tropical waters } & $0 \cdot 77$ & 0.05 & $3 \cdot 14$ & $1 \cdot 08$ & $1 \cdot 17$ & $6 \cdot 21$ & $1 \cdot 12$ \\
\hline $\begin{array}{c}\text { Tropical } \\
\text { 1st } \\
\text { 2nd } \\
\text { 3rd } \\
\text { 4th } \\
\text { 5th } \\
\text { 6th } \\
\text { 7th } \\
\text { 8th } \\
\text { 9th } \\
\text { 10th } \\
\text { 11th } \\
\text { 12th } \\
\text { 13th } \\
\text { 14th } \\
\text { 15th } \\
\text { 16th } \\
\text { 17th } \\
\text { 18th }\end{array}$ & 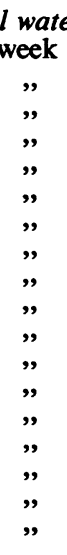 & $\begin{array}{c}\cdots \\
\cdots \\
\cdots \\
\cdots \\
\cdots \\
\cdots \\
\cdots\end{array}$ & 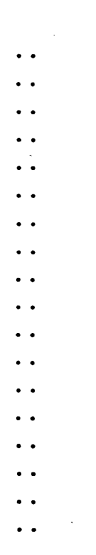 & $\begin{array}{l}. . \\
. \\
. \\
. \\
. \\
. \\
. \\
. \\
. \\
. \\
. \\
. \\
. \\
. \\
. \\
. .\end{array}$ & $\begin{array}{l}0.84 \\
0.98 \\
0.83 \\
0.72 \\
0.88 \\
1.19 \\
1.26 \\
1.26 \\
1 \cdot 11 \\
1.11 \\
1.06 \\
0.79 \\
0.85 \\
0.85 \\
0.74 \\
0.78 \\
0.71 \\
0.88\end{array}$ & $\begin{array}{l}0.12 \\
0.15 \\
0.08 \\
-\overline{0.05} \\
0.06 \\
0.15 \\
0.06 \\
0.09 \\
0.09 \\
-\overline{0} \\
0.12 \\
0.24 \\
0.18 \\
0.10 \\
0.05 \\
0.05 \\
0.12\end{array}$ & $\begin{array}{l}4 \cdot 02 \\
5 \cdot 64 \\
6 \cdot 48 \\
6 \cdot 51 \\
6 \cdot 51 \\
7 \cdot 28 \\
7 \cdot 94 \\
7 \cdot 51 \\
7 \cdot 77 \\
7 \cdot 80 \\
6 \cdot 41 \\
6 \cdot 09 \\
7 \cdot 26 \\
7 \cdot 65 \\
5 \cdot 74 \\
6 \cdot 05 \\
6 \cdot 37 \\
7 \cdot 10\end{array}$ & $\begin{array}{l}1.22 \\
1.64 \\
1.47 \\
1.34 \\
1.35 \\
2.21 \\
2.39 \\
2.28 \\
2.04 \\
1.99 \\
1.79 \\
1.94 \\
2.06 \\
1.79 \\
1.62 \\
2.12 \\
2.02 \\
2.12\end{array}$ & $\begin{array}{l}1 \cdot 29 \\
1.81 \\
1.77 \\
1.80 \\
2 \cdot 14 \\
2.66 \\
2.86 \\
2 \cdot 80 \\
2.45 \\
2.48 \\
2 \cdot 29 \\
2 \cdot 35 \\
2.41 \\
2.62 \\
2.10 \\
1.85 \\
1.76 \\
2.02\end{array}$ & $\begin{array}{r}7 \cdot 49 \\
10 \cdot 23 \\
10 \cdot 63 \\
10 \cdot 37 \\
11 \cdot 13 \\
13 \cdot 40 \\
14 \cdot 60 \\
13 \cdot 91 \\
13 \cdot 46 \\
12 \cdot 47 \\
11 \cdot 55 \\
11 \cdot 29 \\
12 \cdot 82 \\
13 \cdot 09 \\
10 \cdot 30 \\
10 \cdot 85 \\
10 \cdot 91 \\
12 \cdot 24\end{array}$ & $\begin{array}{l}1.43 \\
1.43 \\
1.58 \\
1.34 \\
1.09 \\
1.21 \\
1.34 \\
1.14 \\
0.99 \\
1.20 \\
1.23 \\
1.02 \\
1.18 \\
1.23 \\
0.92 \\
0.87 \\
1.00 \\
1.51\end{array}$ \\
\hline
\end{tabular}


TABLE IX

Comparison between Australian and Tropical Waters, ATtending and Sick Lists, for AVERage of Six-Week Periods (Rates in Australian Waters = 100)

\begin{tabular}{ccc|c|c}
\hline & & & $\begin{array}{c}\text { Attending } \\
\text { List }\end{array}$ & Sick List \\
\hline Australian waters &. &.. & 100 & 100 \\
& & & & \\
Tropical waters & &. & 155 & 186 \\
1st six weeks &. &. & 194 & 159 \\
2nd six weeks & $\ldots$ &.. & 173 & 152 \\
3rd six weeks & $\ldots$ &. & & 166 \\
All eighteen weeks & $\ldots$ &.. & 174 & \\
\hline
\end{tabular}

List rate had risen to over 10 per cent. and increased very uniformly to a maximum in the seventh week. (This wastrue of both ships separately.) Thereafter there was some decline with moderate fluctuations. The Sick List figures ranged only from a minimum of 11 to a maximum of 31 ; accordingly they are shown as totals only. It would be necessary to add together many more ships before weekly differences meant very much, or alternatively, much longer periods would have to be averaged. Averaging six-week periods and taking rates in Australian waters as $\mathbf{1 0 0}$ gives the results shown in Table IX. The figures in Table IX may be compared with the relative rates for these two types of waters for the large aggregates of Table I and Table V. The corresponding relative rates in tropical versus Australian waters are:

$$
\begin{array}{llll}
\text { Attending List } & & \ldots & 184 \\
\text { Sick List } \quad . & \ldots & 153
\end{array}
$$

Agreement is thus quite good. It would not appear, therefore, that the Attending List is intrinsically more valuable as an index than the Sick List, except by virtue of its far larger numbers; but this is a very important advantage. Sick List figures can yield results only if a considerable number of ships or periods are added together. Attending List figures can give results even down to single large ships over short periods. It remains to be seen whether greater precision in defining Attending List cases might not make this List even more valuable.

\section{Movement from Tropical to Temperate Waters}

Two ships provide returns covering the reverse movement, first a period in tropical waters followed

\section{TABLE $X$}

Weekly Percentage Sickness Rates in Two Ships, an Aircraft Repair and Maintenance Ship and a Submarine Depot ShIP, In Tropical Waters, followed by a Period in Temperate Australian Waters

\begin{tabular}{|c|c|c|c|c|c|c|c|c|c|c|}
\hline & & & & \multicolumn{6}{|c|}{ Attending List } & \multirow{2}{*}{$\begin{array}{c}\text { Sick List } \\
\text { Total }\end{array}$} \\
\hline & & & & $\begin{array}{c}\text { Upper } \\
\text { respiratory }\end{array}$ & $\begin{array}{c}\text { Dysenteries } \\
\text { and } \\
\text { diarrhoeas }\end{array}$ & Skin & $\begin{array}{c}\text { Other } \\
\text { diseases }\end{array}$ & Injuries & Total & \\
\hline $\begin{array}{l}\text { Tropical waters } \\
\text { 1st week } \\
\text { 2nd " } \\
\text { 3rd ", } \\
\text { 4th " } \\
\text { 5th " } \\
\text { 6th ", }\end{array}$ & $\begin{array}{l}\cdots \\
\cdots \\
\cdots \\
\cdots \\
\cdots\end{array}$ & $\begin{array}{l}\cdots \\
\cdots \\
\cdots \\
\cdots \\
\cdots\end{array}$ & $\begin{array}{l}. . \\
. \\
. \\
. \\
. \\
.\end{array}$ & $\begin{array}{l}0.69 \\
1.08 \\
1.15 \\
1.08 \\
0.85 \\
0.71\end{array}$ & $\begin{array}{l}0.39 \\
0 \cdot 30 \\
0.26 \\
0.78 \\
0.92 \\
0.44\end{array}$ & $\begin{array}{l}5 \cdot 67 \\
6 \cdot 23 \\
6 \cdot 20 \\
5 \cdot 32 \\
4 \cdot 95 \\
5 \cdot 93\end{array}$ & $\begin{array}{l}2 \cdot 26 \\
2 \cdot 03 \\
2 \cdot 52 \\
3 \cdot 49 \\
3: 32 \\
2 \cdot 88\end{array}$ & $\begin{array}{l}2 \cdot 36 \\
2 \cdot 56 \\
2 \cdot 46 \\
2 \cdot 17 \\
2 \cdot 17 \\
2 \cdot 37\end{array}$ & $\begin{array}{l}11 \cdot 37 \\
12 \cdot 20 \\
12 \cdot 59 \\
12 \cdot 84 \\
12 \cdot 21 \\
12 \cdot 33\end{array}$ & $\begin{array}{l}0.89 \\
1.25 \\
1.18 \\
1 \cdot 12 \\
0.95 \\
1.05\end{array}$ \\
\hline $\begin{array}{c}\text { Week of entry } \\
\text { waters }\end{array}$ & $\begin{array}{l}\text { into } \\
\ldots\end{array}$ & $\begin{array}{l}\text { temper } \\
\ldots\end{array}$ & $\begin{array}{c}\text { rate } \\
\cdot \ldots\end{array}$ & $0 \cdot 61$ & 0.54 & $6 \cdot 47$ & $2 \cdot 44$ & $2 \cdot 00$ & $12 \cdot 06$ & $1 \cdot 08$ \\
\hline $\begin{array}{l}\text { Temperate Austrc } \\
\text { 1st week } \\
\text { 2nd ", } \\
\text { 3rd ", } \\
\text { 4th ", } \\
\text { 5th ", } \\
\text { 6th ", } \\
\text { 7th " } \\
\text { 8th " }\end{array}$ & $\begin{array}{l}\text { alian } \\
\cdots \\
\cdots \\
\therefore \\
\cdots \\
\cdots \\
\cdots \\
\cdots \\
\cdots\end{array}$ & $\begin{array}{l}\text { vaters } \\
. . \\
\ldots \\
\ldots \\
\ldots \\
\ldots \\
\ldots \\
\ldots\end{array}$ & \begin{tabular}{l|}
$\cdots$ \\
$\cdots$ \\
$\cdots$ \\
$\cdots$ \\
$\cdots$ \\
$\cdots$
\end{tabular} & $\begin{array}{l}0 \cdot 36 \\
0 \cdot 25 \\
0 \cdot 22 \\
0 \cdot 14 \\
0 \cdot 25 \\
0 \cdot 32 \\
0 \cdot 49 \\
1 \cdot 06\end{array}$ & $\begin{array}{l}0 \cdot 47 \\
0 \cdot 14 \\
0 \cdot 07 \\
0 \cdot 18 \\
0 \cdot 14 \\
0 \cdot 18 \\
0 \cdot 25 \\
0 \cdot 14\end{array}$ & $\begin{array}{l}6 \cdot 54 \\
4 \cdot 46 \\
2 \cdot 30 \\
2 \cdot 37 \\
2 \cdot 76 \\
3 \cdot 04 \\
3 \cdot 14 \\
3 \cdot 89\end{array}$ & $\begin{array}{l}1 \cdot 55 \\
0 \cdot 83 \\
0 \cdot 86 \\
0 \cdot 97 \\
0 \cdot 99 \\
1 \cdot 24 \\
1 \cdot 10 \\
1 \cdot 70\end{array}$ & $\begin{array}{l}2.08 \\
1.94 \\
1.22 \\
1.04 \\
0.85 \\
0.46 \\
0.64 \\
1.94\end{array}$ & $\begin{array}{r}11 \cdot 00 \\
7 \cdot 62 \\
4 \cdot 67 \\
4 \cdot 70 \\
4 \cdot 99 \\
5 \cdot 24 \\
5 \cdot 62 \\
8 \cdot 73\end{array}$ & $\begin{array}{l}0.68 \\
0.43 \\
0.65 \\
0.83 \\
0.67 \\
0.60 \\
0.53 \\
0.57\end{array}$ \\
\hline
\end{tabular}
(Venereal Diseases and Hospital Discharges omitted) 
by a period in temperate Australian waters. The ships concerned are the same submarine depot ship as before, and an aircraft repair and maintenance ship. The figures are shown in Table $X$.

The reversal of the figures of Table VIII is well shown. Taking the eight weeks in temperate Australian waters as 100 the average total sickness rates for the six weeks in tropical waters are:

$\begin{array}{llll}\text { Attending List } & & \ldots & 187 \\ \text { Sick List } & \ldots & \ldots & 173\end{array}$

Again these proportions accord well with the ratios quoted above for the aggregates of large numbers of ships in these types of waters.

If experience in these ships is typical it would appear that the fall in the rates on passage into temperate waters is rather more rapid than the rise on passage into tropical waters, at least in regard to the Attending List. Table VIII shows a marked rise in the second complete week in tropical waters, followed by a steady further rise up to the seventh week. Table $X$ shows a fall which has reached a minimum by the third week in temperate waters. The Sick List figures of Tables VIII and X seem to suggest that both rise and fall occur more quickly than in the Attending List, but the numbers are too small to make it safe to consider anything less than several weeks taken together. It is perhaps possible that the figures of Table $X$ are somewhat affected by leave being given to members of the ships' companies on reaching an Australian port. This was not mentioned in the Returns, however, and the fact that the minimum did not occur till the third week also makes it unlikely that this factor is of much importance.

\section{Future OF THE RETURNS}

If the return is to be retained it could be simplified. If considered wise, venereal diseases could be omitted altogether. Discharges to hospital should be shown in total only. Finally there is now no reason to require medical officers to work out any rates. An article in the Medical Officers' Bulletin could usefully draw attention to common mistakes.

Any medical officer in a large ship could carry out a very useful piece of research by breaking up the total figures, both for sickness and for total complement, into age-groups; by checking carefully the comparabilities of numerators and denominators at all times, so that returns would not have to be discarded; and by detailing carefully circumstances that might affect either the sickness or the calculations.

\section{APPENDIX}

Return of Sickness Rates from H.M. Ships Afloat (M.D.G. 36398/45-12 Jul.' 1945)

It is becoming increasingly important to compare the sickness rates in different ships. The habitability of ships, the effect of tropical or arctic conditions upon the health of the ship's company, acclimatization and deterioration, and many other problems constantly arise. A preliminary survey carried out recently in the Fastern Fleet has yielded most valuable information. In the near future developments such as air conditioning must be evaluated as regards their effect on health.

It will be appreciated that the Medical Officers' Journal can provide information only after the lapse of many months - the Journal is, in fact, adapted for the collection of long-term statistics. Furthermore, no information is provided as to the number of cases on the Attending List, and it may well be that it is the amount of minor sickness which will sometimes provide the better measure of inefficiency due to adverse conditions.

Accordingly, it has been decided to institute a simple type of return which will enable, in the first place, the ship's medical officer to follow, according to a standard and uniform plan, the health record of his ship. Secondly, the Fleet Medical Officer will be able to obtain a rapid survey of the state of health in the ships of his particular Fleet. Finally, information will be available for all the ships of the Fleet; sickness can be compared in tropical as against home waters and in ships of different types: the effect of movement from temperate to tropical waters or vice versa can be followed month by month. These are a few of the benefits of the new return.

1. In order that full advantage may be taken of the new return it is necessary that the procedure shall be simple, rapid, and uniform. The ship's medical officer and the Fleet Medical Officer should know the sickness rates immediately after the close of the period to which they refer. Centrally, the Medical Director-General's Department will be able to complete its analysis for the whole Fleet with no more delay than is entailed by the transmission of the returns. Uniformity of procedure is obviously essential if ship and ship are to be compared.

2. Experience shows that a very simple procedure is sufficient for all practical purposes. It is enough to count at a predetermined time once a week every case in the Sick and Attending Lists, supplementing these by a count of cases sent to hospital during that week. Cases are divided into a few broad groups only.

3. The new return will be made only by ships carrying a medical officer. It will not be made by shore establishments nor by hospital ships. Medical officers in parent ships will make returns for their parent ship only and not respecting personnel in tenders.

4. The new return will not at present supersede any other.

5. The fixed time each week to which the count will refer is at 23.59 on each Wednesday. Returns will be made each calendar month and will include four or five weekly counts, depending upon how many Wednesdays there are in the particular calendar month. The figures 
for the last Wednesday of the previous calendar month will also be included so that the rate for the first weekly period can be worked out. Nil returns are to be made. Immediately after the last count of the calendar month two copies will be prepared. One will be forwarded to the Fleet Medical Officer and one to the Medical DirectorGeneral, Admiralty, London, quoting this Order on each return.

6. Providing that no appreciable change takes place in the strength of the ship's company during the month, it will be sufficient to give a single average figure, as shown in the specimen return. If there is appreciable change during the month, however, for example on commissioning, owing to disembarkation of aircrews, etc., the average strength will be given for each week separately.

7. In calculating strength and number of cases, officers and ratings will be included together.

8. The count of Sick List cases (with Excused Duty List cases) will include all those who are excused duty as at 23.59 on the Wednesday in question.

9. It will be appreciated that in order to secure uniformity and make it possible to compare ship and ship, what constitutes an Attending List case has to be strictly defined. For the purposes of this Return a patient will be regarded as being on the Attending List when he attends at the sick bay and is instructed to report again within a period not exceeding a fortnight. Single visits with no instruction to return will not be included. When the patient is told that he need not attend again, or not within a period of a fortnight, he will no longer be shown in the return. No distinction will be made between those on light duty and those on full duty.

10. In view of possible differences of procedure regarding discharge from the ship's books of those sent to hospital, it is not possible to make a simple count of men in hospital as at 23.59 each Wednesday. Instead the figure (unlike those of the Sick and Attending Lists) will refer to the number of cases discharged to hospital during the week ending at $\mathbf{2 3 . 5 9}$ on Wednesday.

11. The few broad disease groups chosen are designed particularly for investigating habitability and the effect of differences in climate. The disease group " upper respiratory infections " will comprise infections of the nose, sinuses, nasopharynx, larynx and trachea, including influenza, colds, sore throats, and Vincent's infection; it will not include disease of the bronchi and lungs. " Diseases of the skin " will include boils, otitis externa, tropical ulcers, and mycotic infections. Scabies and pediculi will be included with "All other diseases" and not under " diseases of the skin."

As in the certification of deaths, serious disease following a very trivial injury will be classified as disease and not as injury: for example septicaemia following a scratch and all tropical ulcers.

Illness due to noxious agents, bites or stings, attempted suicide or extremes in physical conditions, for example heat stroke or frostbite, will be classified as injury.

12. There must be no duplication of cases, that is, one and the same man can only appear once in the weekly count. If he is suffering from more than one illness and could be included under more than one disease heading the medical officer will decide on a primary diagnosis and the man will be so classified. The Sick List takes precedence over the Attending List. For example if a man returned as on the Attending List at a given Wednesday midnight owing to a skin condition, subsequently develops a cold and is on the Sick List at midnight the following Wednesday, he will be shown in the second Wednesday's count under " Sick List-upper respiratory infections." If by the third Wednesday he has been discharged from the Sick List, but remains on the Attending List owing to his skin condition he will once again appear under "Attending List-skin diseases " in the count for the third Wednesday.

If a man is on the Attending List for more than one disease, the medical officer will decide on the primary diagnosis.

Venereal diseases raise a special problem. Men attending regularly for treatment will be shown under the appropriate heading; if, however, they develop any other illness necessitating their being placed on the Attending List they will be classified according to that illness and not under " venereal diseases." Only when the second illness is concluded will they revert to "Attending List-venereal diseases." , It will be appreciated that there are other ways of studying venereal diseases and that the chief purpose of having a separate heading in this return is to avoid the obscuring of trends of sickness due to other causes by fluctuations in the amount of venereal disease.

There is little chance of duplication between hospital and Sick or Attending List cases. A man already discharged to hospital during the week ending at $\mathbf{2 3 . 5 9}$ on Wednesday cannot appear on either list. Should he have been on either at $\mathbf{2 3 . 5 9}$ on the previous Wednesday he will, of course, have been properly included in that previous week's count. In the unlikely event of a man being discharged to hospital and rejoining the ship under the week, then being placed on the Sick or Attending List, he will be classified under hospital discharge, that is, hospital discharges take precedence over Sick or Attending Lists.

13. For the purposes of this confidential return, there will be no security objection to detailing the movements of ships. It will be appreciated that what is required is a full résumé with dates. What is important is (a) whether the ship is in port and, if so, in what ports; (b) if at sea, in approximately what waters. Periods in port can easily be recorded with names and dates. Should it be known to the medical officer that certain diseases are prevalent in a particular port, it will be helpful if the facts are stated. If the ship is proceeding to sea daily for exercises, it will be sufficient to mention that fact in all brevity.

In the event of a direct journey from one port to another it will be sufficient to give the names together with dates of departure and arrival; voyages not covered in this way, however, will require more specific description, for example, " left Scapa Flow, May 4, on convoy duty, sailed to latitude approximately . . ., returned Scapa Flow, May 15." During a long cruise the ship might be in very different kinds of waters climatically, and the 
mere listing of ports and dates of departure and arrival would not cover this.

14. Should it be considered that any figures have been substantially affected by some special circumstances, for example an outbreak of infectious disease, action, serious accident, etc., a symbol such as an asterisk will be attached to the figures so affected and a note made under "remarks."

(Further paragraphs dealt with the calculation of percentage rates and included a specimen form.)

\section{SUMMARY}

A new return of sickness was instituted in the Royal Navy in 1945. This called for a weekly census count of the sick and of the strength of the ship's company. As it was thought that the amount of minor sickness might prove especially valuable as a measure of habitability, the numbers on the Attending List (full duty and light duty) were called for as well as the numbers on the Sick List (excused duty). Diseases were grouped under a few broad headings.

An analysis of returns has been made for the first year of operation. The value of including those on the Attending List was fully confirmed, for, being ten times more numerous than those on the Sick List, monthly or even weekly fluctuations in a big ship can prove meaningful, while trends based on the averaging of relatively large numbers were almost if not quite as definite as in the Sick List.

It was found that sickness varied notably in relation to type of water. Thus total rates were more than doubled in tropical as contrasted with northern temperate waters, diseases of the skin being increased from three to four times. In contrast the differences between ships of various types proved very small, the only definite finding being a moderate increase in depot, repair, and maintenance ships. The effect of seasonal variation in temperate waters also proved to be relatively small, the only considerable fluctuation being the expected winter increase in upper respiratory diseases in northern temperate waters.

In a few ships it was possible to follow for a sufficient period the changes in the sickness rates as these ships moved from temperate to tropical waters and vice versa. The changes in the rates agreed well with the figures based on the relatively large aggregates mentioned above. The rise on passing into tropical waters and the fall on passing into temperate waters occurred rapidly and were well established by the third week.

I am greatly indebted to the Medical Director-General of the Navy for permission to publish this report. 